\title{
Эльзара Мустафаева
}

аспирантка кафедры регионального управления и регионалистики Одесского регионального института государственного управления Национальной академии

государственного управления при Президенте Украины, г. Одесса, Украина, e-mail:elzaramustafaeva13@gmail.com,https://orcid.org/0000-0002-1736-7138

\section{МЕЖДУНАРОДНОЕ ИЗМЕРЕНИЕ УЧЁТА ЭТНИЧЕСКОГО ФАКТОРА ПРИ ОСУЩЕСТВЛЕНИИ ТЕРРИТОРИАЛЬНЫХ ПРЕОБРАЗОВАНИЙ В УКРАИНЕ}

Аннотация. Статья посвящена анализу международных стандартов учета этнического фактора при реализации территориальной реформы. Обозначены особенности этнотерриториального устройства Украины в контексте административно-территориальной реформы 2015-2020 гг. В статье подробно анализируются требования Декларации прав лиц, принадлежащих к национальным, этническим, религиозным или языковым меньшинствам, которые имеют решающее значение для территориальной реформы. Рассматривается Декларация прав коренных народов, в которой рассматриваются коллективные права, включая право на самоопределение, права на земли, территории и ресурсы, а также культурные права. Рассмотрены подходы, нацеленные на этнотерриториальные аспекты (заявленные в Гаагских рекомендациях по правам национальных меньшинств на образование и в рекомендациях Осло по языковым правам национальных меньшинств). Среди международных документов, имеющих обязательства для Украины, - Рамочная конвенция о защите национальных меньшинств, Европейская хартия региональных языков и языков меньшинств и Европейская хартия местного самоуправления. Некоторые международные договоры Украины с соседними государствами были проанализированы с точки зрения сохранения самобытности соответствующих этнических групп, в том числе касающиеся сохранения пропорционального состава населения на территориях проживания лиц, принадлежащих к национальным меньшинствам.

Ключевые слова: национальные меньшинства, межэтнические отношения, международные стандарты, административно-территориальная реформа, добровольное объединение территориального сообщества, этнонациональная политика. 


\title{
Elzara Mustafaieva
}

PhD student of the Public Administration and Regional Study Department, Odessa Regional Institute for Public Administration, National Academy for Public Administration under the President of Ukraine, 65000, Odessa, Ukraine, e-mail: elzaramustafaeva13@gmail.com, https://orcid.org/0000-0002-1736-7138

\section{CONSIDERATION OF INTERNATIONAL LEGAL ACTS IN THE NATIONAL LEGISLATION OF UKRAINE IN THE IMPLEMENTATION OF TERRITORIAL TRANSFORMATIONS}

\begin{abstract}
The article is devoted to the analysis of international accounting standards of the ethnic factor in the implementation of territorial reform. The features of the ethno-territorial structure of Ukraine in the context of the administrative-territorial reform in 2015-2020 are outlined. The article analyzes in detail the requirements of the Declaration of the Rights of Persons Belonging to National, Ethnic, Religious or Linguistic Minorities that are decisive for territorial reform. The Declaration on the Rights of Indigenous Peoples, which deals with collective rights, including the right to self-determination, rights to lands, territories and resources, and cultural rights is considered. The approaches aimed at ethno-territorial aspects (declared in The Hague recommendations on the rights of national minorities in education and The Oslo recommendations on the linguistic rights of national minorities) are examined. Among the international documents having obligations for Ukraine are the Framework Convention for the Protection of National Minorities, the European Charter for Regional and Minority Languages and the European Charter on Local SelfGovernment. Some international treaties of Ukraine with neighboring states have been analyzed in terms of preserving the identity of the respective ethnic groups, including those concerning the preservation of the proportional composition of the population in the areas where persons belonging to national minorities live.
\end{abstract}

Keywords: national minorities, interethnic relations, international standards, administrative and territorial reform, voluntary association of territorial community, ethno-national policy.

Постановка проблеми. Начиная с 2015 г., в Украине последовательно реализуется реформа территориальных основ публичной власти. В период 2015-2019 гг. она проходила в формате т.н. добровольного объединения низового звена территориального деления - территориальных громад. В июне 2020 г. произошло окончательное объединение территориальных громад уже по решению правительства Украины. По результатам объединения на базе почти 12.000 территориальных громад в Украине было сформировано 1469 новых громад. Кроме этого, в июле 2020 г. произошло реформирование также и срединного звена территориального деления - 
районов. Вместо 490 административных районов были создан 136 новых.

Однако проведение территориальных преобразований сталкивается с рядом проблем в местах компактного проживания национальных меньшинств, что является следствием опасения этнических групп уменьшения уровня обеспечения своих этнонациональных прав в результате реформирования. Вследствие указанного, процессы добровольного объединения территориальных громад были замедлены в местах компактного проживания венгров (59 громад), румын (40 громад), молдаван (51 громада), болгар (47 громад), гагаузов (5 громад), поляков (2 громады), албанцев (1 громада), а также в громадах с высоким уровнем полиэтничности (около 900 громад). К последим относятся также те громады, где компактно проживают один из коренных народов Украины - крымские татары. При этом наиболее полиэтничными регионами Украины являются Закарпатская, Черновицкая и Одесская области (рис. 1-3).

Принудительное объединение территориальных громад, а также образование новых районов в местах компактного проживания национальных меньшинств по решению правительства Украины также вызвало ряд недоразумений, хотя эффективность указанных решений пока трудно оценить.

Можно констатировать, что механизмы осуществления территориальных преобразований в местах компактного проживания национальных меньшинств в Украине фактически не отработаны. В связи с этим не случайно, что резолюция ПАСЕ № 2145 от 25 января 2017 г. [1] о функционировании демократических институтов в Украине отметила, что процесс децентрализации является важным для стабильности и укрепления демократии в Украине в целом, а также учитывая этнический состав регионов. Согласно четвертому выводу Консультативного комитета Рамочной конвенции Совета Европы о защите национальных меньшинств в Украине, Консультативный комитет призывает украинские власти обеспечить, чтобы при изменении административных границ были бы гарантированы права национальных меньшинств [2].

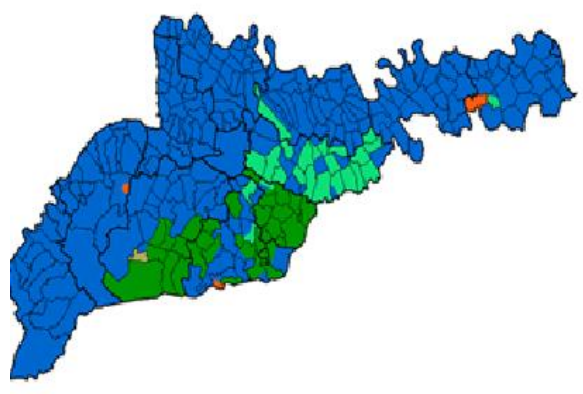

Украинцы

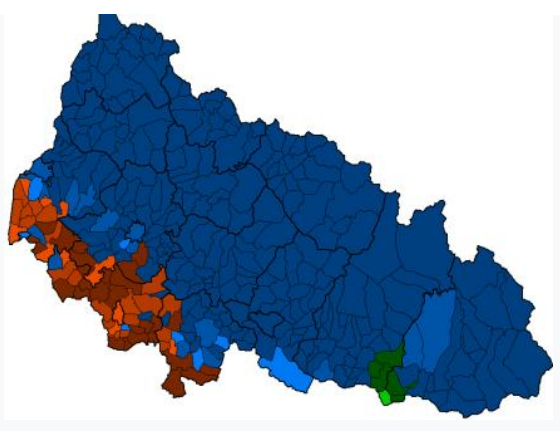

венгры
румыны

Рис. 1. Распределение этнических Рис. 2. Распределение этнических групп в Черновицкой области групп в Закарпатской области 

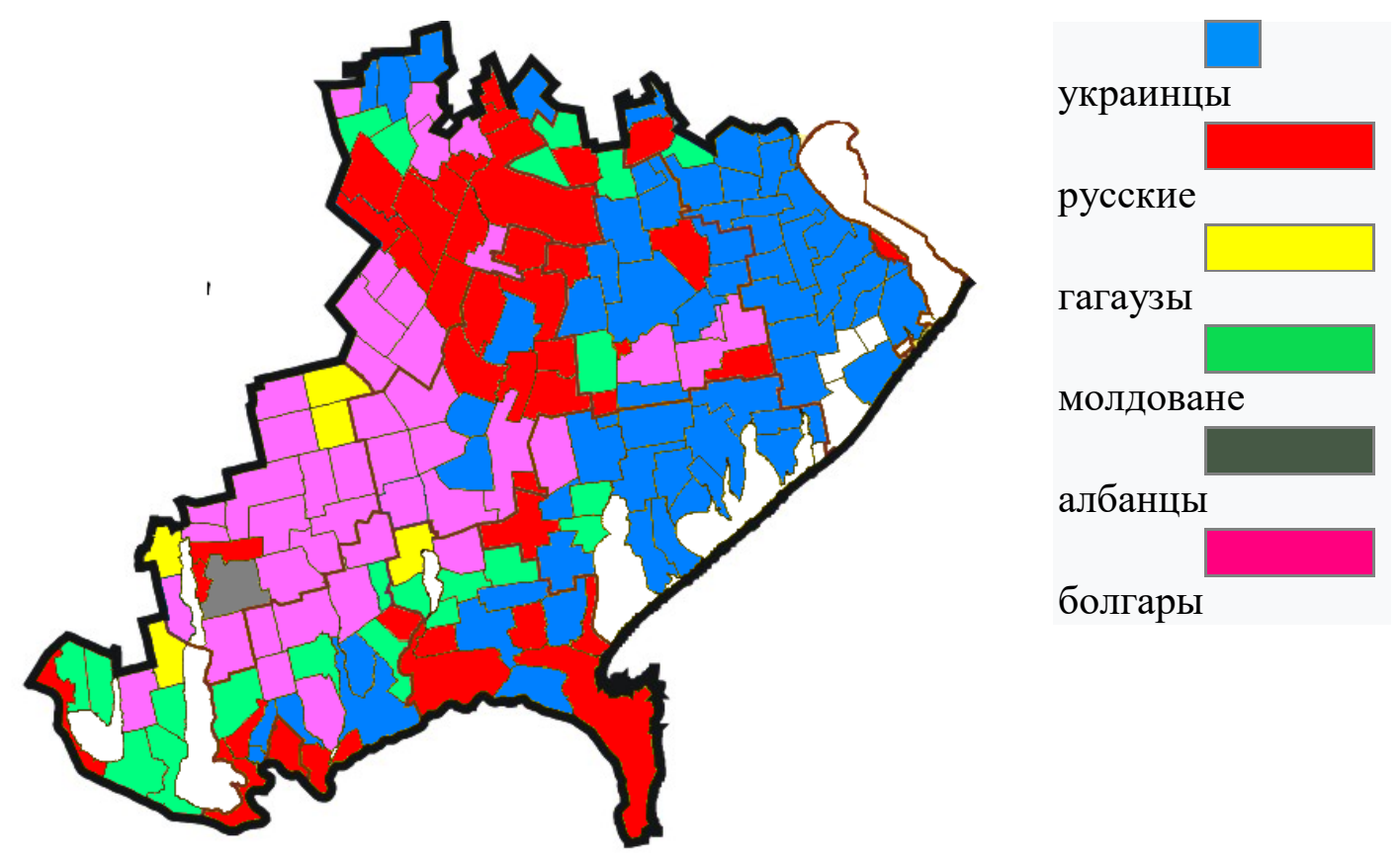

Рис. 3. Распределение этнических групп в южных районах Одесской области

Цель статьи. Определение международной правовой основы относительно учета этнического фактора при осуществлении территориальных преобразований в Украине.

Изложение основного материала. В соответствии с Конституцией Украины действующие международные договоры, согласие на обязательность которых принято Верховным Советом Украины, являются частью национального законодательства Украины. В связи с указанным, международные нормы относительно учета этнического фактора при осуществлении территориальных преобразований имеют большое значение.

В основу международных стандартов по защите прав национальных меньшинств положен Международный пакт о гражданских и политических правах [3], согласно которому в тех странах, где существуют этнические и языковые меньшинства, лицам, принадлежащим к таким меньшинствам, не может быть отказано в праве совместно с другими членами той же группы пользоваться своей культурой, а также пользоваться родным языком. Данный документ признает права национальных меньшинств как часть общих прав человека, что и вызвало необходимость разработки специального документа о признании особых прав лиц, принадлежащих к национальным меньшинствам.

В результате длительных исследований и согласований, Резолюцией 47/135 Генеральной Ассамблеи ООН от 18.12.1992 была утверждена Декларация правах лиц, принадлежащих к национальным, этническим, религиозным или языковым меньшинствам (далее - Декларация меньшинств) [4]. И хотя она не является юридически обязывающим документом, тем не менее, его положения были положены в основу всех последующих 
международных стандартов по защите прав национальных меньшинств [5, с. 16].

В этом базовом документе за лицами, принадлежащими к таким меньшинствам, признаются конкретные права на: родину (статья 1); пользование родным языком как в частной жизни, так и публично; исповедование своей религии и отправления религиозных обрядов (ч.1 статьи 2); участие в принятии решений как на местном, так и на государственном уровне по вопросам, касающихся их национальной жизни (ч.3 статьи 2); создание собственных организаций; поддержку свободных контактов с членами своей группы как в пределах своей страны, так и за рубежом (ч.4 статьи 2); равенство перед законом (ч.1 статьи 4); защита от дискриминации (ч.1 статьи 3); свободное развитие культуры, языка, религии, традиций, обычаев (ч.2 статьи 4); изучение родного языка или обучения на родном языке (ч.4 статьи 4); участие в экономической и социальной жизни своей страны (ч.5 статьи 4).

В Декларации меньшинств, закреплен ряд основных обстоятельств, которые могут иметь значение в процессе осуществления прав национальных меньшинств. В частности, лица, компактно проживающих на любой части территории государства, в отличие от лиц, проживающих дисперсно, могут рассчитывать на больший объем прав. Также лица, проживающие на территории государства изначально, т.е. являясь коренным народом, могут рассчитывать на более широкие права по сравнению с теми лицами, которые прибыли в результате миграции.

Декларация меньшинств исходит из того, что права национальных меньшинств, отличаются от прав народов на самоопределение, ведь первые это индивидуальные права даже при том, что в большинстве случаев эти права могут осуществляться лицами только совместно с другими; во втором случае - это коллективное право [6]. Хотя право народов на самоопределение четко предусматривается международным правом, в том числе в Международном пакте по правам человека, оно не применяется к лицам, принадлежащим к меньшинствам. Однако обязанность государства сохранять самобытность меньшинств и обеспечивать их эффективное участие может осуществляться путем предоставления автономии в языковых или более широких культурных вопросах.

Обратим, прежде всего, внимание на те положения Декларации меньшинств, которые важны для процессов подготовки, рассмотрения и принятия решений по территориальному реформированию.

Согласно п. 1.1. Декларации меньшинств, государства должны охранять на соответствующих территориях существование и самобытность национальных или этнических, культурных, религиозных и языковых меньшинств и поощрять создание условий для развития этой самобытности. Таким образом, защита национальных меньшинств базируется на четырех требованиях: защита существования, неисключенность, недискриминация и неассимиляция. Примечательно использования в Декларации меньшинств термина «самобытность», что отражает четкую тенденцию к защите и 
поощрении культурного разнообразия. Защита самобытности групп меньшинств требует не только терпимости, но и позитивного отношения государства и общества в целом к принципу культурного плюрализма. Для обеспечения самобытности нужно не только признавать, но и уважать отличительные особенности и вклад меньшинств в жизнь общества в целом. Защита самобытности означает, что государство должно воздерживаться от проведения политики, целью или следствием которой является ассимиляция меньшинств в рамках доминирующей культуры. В связи с этим решающее значение имеет политика в сфере языка и образования. Лишение меньшинств возможности изучать родной язык или исключение из процесса образования меньшинств элемента передачи накопленных ими знаний об их собственной культуре, истории, традиции и языка, представляют собой нарушение принципа защиты самобытности меньшинств.

В соответствии с п. 2.3. Декларации меньшинств лица, принадлежащие к меньшинствам, имеют право активно участвовать в принятии решений на национальном и, где это необходимо, региональном уровне, касающихся меньшинства, к которому они принадлежат, или тех регионов, в которых они проживают. Поскольку такие решения имеют особое влияние на национальные меньшинства, упор на активное участие предусматривает их право на участие в процессе принятия решений уже на начальных его стадиях, ведь эффективность их участия только на завершающих стадиях является низкой, когда достижение компромисса является уже маловероятным. Меньшинства должны участвовать на местном, национальном и международном уровнях в процессе разработки и принятии решений, а также контроля за их реализацией.

Активное участие предполагает наличие каналов для консультирования меньшинств и правительств. Этот принцип может служить средством решения споров и сохранения разнообразия в качестве одного из условий динамической стабильности общества. Необходимо, чтобы меньшинства, как минимум, имели право на то, чтобы их мнения были услышаны и приняты во внимание до принятия решений, затрагивающих их интересы. Разнообразие групп меньшинств с точки зрения их состава, потребностей и стремлений требует в каждом конкретном случае определение и применение наиболее эффективных мер с целью создания условий для их активного участия. В частности, должны учитываться следующие факторы: проживают лица, принадлежащие к соответствующему меньшинству дисперсно или компактно; принадлежит соответствующая меньшинство к категории малых или больших меньшинств, а также к категории «старых» или «новых» меньшинств.

Активное участие требует представленности в законодательных, исполнительных и консультативных органах, а также в различных сферах публичного управления. Лица, принадлежащие к меньшинствам, имеют право на свободу собраний и создание своих ассоциаций, что содействует максимально возможном учету их интересов и ценностей в процессе 
принятия решений на национальном и региональном уровнях. Они не только имеют право на создание и использование этнических, культурных и религиозных ассоциаций и обществ, но и право создавать политические партии, если в этом есть необходимость.

Отметим, децентрализация власти на основе принципа субсидиарности только повышает шансы меньшинств на участие в процессе принятия решений по вопросам, касающимся их самих и всего общества, в котором они живут. Кроме того, в рамках соответствующих институциональных структур должны быть созданы совещательные или консультативные органы по проблемам меньшинств. Такие органы должны иметь политический вес и активно привлекаться к консультированию по вопросам, затрагивающим меньшинства.

Меньшинства также, согласно Декларации меньшинств, имеют право устанавливать и поддерживать без какой-либо дискриминации свободные и мирные трансграничные контакты с гражданами других государств, с которыми они связаны национальными, этническими, религиозными или языковыми отношениями. Право на поддержку трансграничных контактов является важным элементом, предусмотренным Декларацией меньшинств и способствует устранению ряда негативных проявлений по результатам разделения этнических групп границами государств. Однако такие контакты должны быть не только «свободными», но и «мирными».

Согласно пункту 3.1. Декларации меньшинств лица, принадлежащие к меньшинствам, могут осуществлять свои права, как индивидуально, так и совместно с другими членами своей группы без какой-либо дискриминации. Этот принцип имеет особое значение, поскольку правительства часто достаточно толерантно относятся к лицам другого национального или этнического происхождения до тех пор, пока они не начинают отстаивать свое право на самобытность, язык и традиции. Во многих случаях дискриминация или преследование начинаются именно после заявлений о своих правах в качестве лиц, принадлежащих к определенной группе. Таким образом, лица, принадлежащие к меньшинствам, не должны подвергаться дискриминации на основании того, что они демонстрируют самобытность своей группы.

Статья 4.1 требует, чтобы государства принимали при необходимости меры для обеспечения лицам, принадлежащим к меньшинствам, в полной мере и эффективно осуществлять все свои права человека и основные свободы, без какой-либо дискриминации и на основе полного равенства перед законом. Хотя, согласно международному праву, на государство возложено общее обязательство обеспечивать, чтобы все члены общества могли осуществлять свои права человека, тем не менее, государства должны уделять особое внимание осуществлению прав человека лицами, принадлежащими к меньшинствам по той причине, что они сталкиваются с особыми проблемами. Меньшинства находятся в более уязвимом положении и в прошлом довольно часто подвергались дискриминации. Для обеспечения 
фактического равенства в некоторых обстоятельствах может понадобиться, чтобы государство принимало временные меры в контексте позитивной дискриминации, как это предусмотрено в статье 2.2 Международной конвенции о ликвидации всех форм расовой дискриминации [7], положение которой могут быть применены также к национальным меньшинствам.

Согласно п. 4.2. Декларации меньшинств государства должны принимать меры для создания благоприятных условий, позволяющих лицам, принадлежащим к меньшинствам, выражать свои особенности и развивать свою культуру, язык, религию, традиции и обычаи. Этот пункт требует не просто терпеливого отношения к проявлениям различных культур в рамках государства. Создание соответствующих благоприятных условий требует принятия активных мер со стороны государства. Осуществление таких мер может потребовать от государства привлечения соответствующих экономических ресурсов - так же, как государство выделяет средства на цели развития культуры и языка большинства населения, оно должно также выделять ресурсы для осуществления аналогичной деятельности и в интересах меньшинств.

Немаловажным является пункт 4.3 Декларации меньшинств, согласно которому государства должны принимать соответствующие меры для того, чтобы там, где это возможно, лица, принадлежащие к меньшинствам, имели надлежащие возможности для изучения своего родного языка или обучения на родном языке. Это является следствием того, что язык является одним из наиболее важных признаков самобытности группы. Для соответствующих мероприятий особое значение приобретает размер группы и характер ее расселения на территории страны: компактный или дисперсный. Кроме того, важно и то, есть ли соответствующая группа укоренившейся меньшинством или меньшинством, состоящий из недавних эмигрантов. В тех случаях, когда языком меньшинства является территориальная язык, на котором традиционно говорят и которую используют многие группы, населяющие соответствующий регион страны, государства должны максимально в пределах имеющихся ресурсов обеспечивать сохранение такой языковой самобытности. Поскольку лица, принадлежащие к меньшинствам, как и лица, принадлежащие к большинству населения, обязаны интегрироваться в общество на общенациональном уровне, им также необходимо изучать официальный или государственный язык. В тех случаях, когда в стране существует большое языковое меньшинство, его язык также может получить статус официального языка государства.

Чрезвычайно важным в контексте территориальных преобразований в Украине является статья 5.1, согласно которой национальная политика и программы должны планироваться и осуществляться при должном учете законных интересов лиц, принадлежащих к меньшинствам. Указанные интересы не касаются только чисто экономических аспектов территориальное планирование и территориальное развитие, политика в сфере образования, здравоохранения, обеспечения жильем и т.д. также 
принадлежит к числу тех многочисленных аспектов социальной жизни, требуют учета интересов меньшинств.

Следует отметить, что в рамках $\mathrm{OOH}$, осуществляется разграничение между правами лиц, принадлежащих к меньшинствам, и правами коренных народов [8]. Коренные народы являются этническими сообществами, этногенез которых происходил в пределах современных границ Украины. Коренные народы имеют особые интересы, которые не нашли должного закрепления в Декларации меньшинств. Главным нормативным актом глобального уровня, в котором рассматриваются права коренных народов, является Декларация о правах коренных народов [9] (Украина воздержалась при голосовании по ней на Генеральной Ассамблее ООН), в которой, в отличие от Декларации меньшинств, указывается на признание коллективных, а не индивидуальных прав коренных народов. В Декларации коренных народов рассматриваются коллективные права, включая право на самоопределение, права на земли, территории и ресурсы, а также культурных правах.

Право на самоопределение закрепляется в статье 3 Декларации коренных народов, где указано, что «Коренные народы имеют право на самоопределение. Учитывая это, они свободно устанавливают свой политический статус и свободно осуществляют свое экономическое, социальное и культурное развитие». Данная статья связана со статьей 4, в которой подчеркивается, что «Коренные народы при осуществлении своих прав на самоопределение имеют право на автономию или самоуправление в вопросах, относящихся к их внутренним и местным делам, а также и в вопросах финансирования их автономных функций». Однако в связи с опасением государств, что реализация права на самоопределение может привести сепарацию территорий, в Декларации коренных народов содержится предостережение, что ничто в настоящей Декларации не может быть истолковано как санкционирующее или поощряющее действия, которые вели бы к разобщению, к частичному или полному нарушению территориальной целостности и политического единства суверенных и независимых государств.

Таким образом, право на самоопределение коренные народы могут реализовать через автономные структуры разного рода (территориальные или экстерриториальные), а также через договоры, соглашения и другие договоренности, которые заключались между коренными народами, государствами и/ или другими сторонами, не относящихся к коренным народам.

Существенную озабоченность коренных народов вызывает тот факт, что на государственном уровне иногда принимаются решения, которые затрагивают жизнь коренных народов, но последних не привлекают к участию в принятии таких решений. Именно поэтому Декларация коренных народов четко устанавливает стандарты права на участие в принятии решений по широкому кругу вопросов, непосредственно касающихся жизни 
коренных народов. В частности, статья 18 Декларации коренных народов провозглашает, что «Коренные народы имеют право на участие в принятии решений по вопросам, которые затрагивали бы их права, через представителей, избираемых ими самостоятельно по своим собственным процедурам, а также на сохранение и развитие своих собственных учреждений, принимающих решения». Разница между внутренней и внешней сферами принятия решений также содержится в статье 5 Декларации коренных народов, в которой отмечается: «Коренные народы имеют право сохранять и укреплять свои особые политические, правовые, экономические, социальные и культурные институты, сохраняя при этом свое право, если они этого желают, на полное участие в политической, экономической, социальной и культурной жизни государства». Это право имеет особое значение, поскольку предоставляет коренным народам возможность также быть субъектами, принимающими решения по вопросам государственной важности, в том числе касающихся территории их компактного проживания.

В пункте 2 статьи 32 Декларации коренных народов подчеркивается, что государства добросовестно консультируются и сотрудничают с соответствующими коренными народами через их представительные институты с целью получить их свободное и осознанное согласие относительно утверждения любого проекта, который затрагивает их земли или территории и другие ресурсы, особенно в связи с освоением, использованием или разработкой полезных ископаемых, водных или других ресурсов. Вышесказанное должно стать ключевым положением при рассмотрении законодательства или мероприятий, которые будут касаться прав коренных народов на их земли, территории и природные ресурсы.

Декларация коренных народов закрепляет минимальные стандарты земельных прав коренных народов. Эти права изложены в ряде статей Декларации коренных народов, при этом одной из наиболее значимых является статья 26. В ней изложены общее право коренных народов на земли, территории и ресурсы, которыми они традиционно владели, которые они традиционно занимали или тем или иным образом использовали или получили. Подчеркивается, что государства должны обеспечить правовое признание и защиту земель, территорий и ресурсов коренных народов при должном уважении к их обычаям, традициям и систем землевладения.

Под влиянием ООН весьма существенно продвинулся региональный нормотворческий процесс в сфере защиты прав меньшинств. В Заключительном акте Совещания по безопасности и сотрудничеству в Европе 1975 г. подчеркивалось, что государства-участники, на территории которых представлены национальные меньшинства, будут уважать право лиц, принадлежащих к таким меньшинствам, на равенство перед законом, будут предоставлять им полную возможность фактического пользования правами человека и основными свободами и будут таким образом защищать их законные интересы в этой сфере [10]. В процессе выполнения Заключительного акта, ОБСЕ разработала Гаагские рекомендации о правах 
национальных меньшинств в сфере образования (1996 г.) [11], Ословские рекомендации о языковых правах национальных меньшинств (1998 г.) [12].

Наиболее важным документом в пределах предмета нашего исследования являются Лундские рекомендации об эффективном участии национальных меньшинств в общественно-политической жизни (1999 г.) [13], согласно которым создание всесторонних возможностей для равноправного осуществления прав человека лицами, принадлежащими к меньшинствам, предполагает их эффективное участие в процессе принятия решений, особенно тех, которые их непосредственно касаются.

Согласно Лундских рекомендаций государства должны предоставлять меньшинствам доступ к реальным рычагам влияния как на уровне центральных, так и региональных органов власти, в том числе путем создания для этого специальных механизмов. В зависимости от обстоятельств, эти механизмы могут включать:

специальные формы представительства национальных меньшинств, например, резервирование за ними определенного количества мест в парламенте или в парламентских комитетах, a также другие формы гарантированного участия в законодательном процессе;

официальные или неофициальные договоренности о закреплении за представителями национальных меньшинств постов в правительстве, мест в верховном или конституционном суде или в судах низших инстанций;

обеспечение представленности меньшинств в законотворческом процессе, в частности путем создания одномандатных округов в местах компактного проживания национальных меньшинств;

создание консультативных и совещательных органов в качестве каналов для диалога между государственной властью и национальными меньшинствами;

внедрение механизмов не территориального и / или территориального самоуправления национальных меньшинств, к функциям которого должны отойти вопросы образования, культуры, использования языков меньшинств, а также вопросы социального развития [14].

Основными международными документами европейского уровня обязывающего характера в контексте темы работы является Рамочная конвенция о защите национальных меньшинств [15], Европейская Хартия региональных языков и языков меньшинств [16] и Европейская Хартия местного самоуправления [17].

Рамочная конвенция о защите национальных меньшинств в целом развивает принципы вышеупомянутых документов, однако они приобретают обязательственного характера для государств - членов Совета Европы. В Рамочной конвенции представлен ряд статей, имеющих территориальный характер применения. В частности, ст.ст. 10, 11, 14, закрепляют, что в местах компактного проживания национальных меньшинств должны быть обеспечены:

использование языка меньшинства во взаимодействии с органами 
публичной власти;

размещения топонимов на языке национального меньшинства;

преподавания языка меньшинства или обучение на этом языке.

Новеллой Рамочной конвенции в отличие от вышеупомянутых документов является положение ст. 16, согласно которой государства должны воздерживаться от принятия мер, которые изменяют пропорциональный состав населения в местностях, где проживают лица, принадлежащие к национальным меньшинствам, и которые направлены на ограничение прав и свобод, вытекающих из принципов, изложенных в настоящей рамочной конвенции. Указанная статья предусматривает, в частности принятие во внимание этнического фактора при осуществлении территориальных преобразований, изменений границ избирательных округов, а также округов деятельности судебных органов и других структур [18]. Понятно, что уменьшение веса определенной этнической группы в территориальном разрезе может сделать невозможным эффективную реализацию других прав национальных меньшинств, в т.ч. право на использование родного языка во всех сферах общественной жизни. В связи с указанным примечательно, что в четвертом периодическом докладе о выполнении указанной Рамочной конвенции [2] (2015) уже в пределах начатого процесса объединения территориальных громад, Украина отчиталась об отсутствии отклонений от требований ст. 16 Рамочной конвенции.

Под защитой Европейской хартии региональных языков и языков меньшинств находятся языки, традиционно использующиеся в пределах определенной территории государства гражданами этого государства, которые составляют группу, по своей численности меньше, чем остальное население этого государства и отличаются от официального языка (языков) этого государства [19]. Причем под «территорией, на которой используется региональный язык или язык меньшинства» понимается географическая местность, где такой язык является средством общения, определенного количества лиц, что оправдывает осуществление различных охранных и поощрительных мероприятий, предусмотренных в Хартии. Кроме прав на использование языка и образование на соответствующем языке статья 1 Европейская Хартия региональных языков и языков меньшинств подчеркивает необходимость уважать границы каждой географической местности, в которой используется региональный язык или язык меньшинства, с целью обеспечения, чтобы существующее ранее или новое территориальное деление не создавало препятствий развитию соответствующего регионального языка или языка меньшинства.

Таким образом, хотя с точки зрения Хартии региональных языков и языков меньшинств считается желательной определенная связь между территорией, на которой используется та или иная региональная речь и соответствующей территориальной единицей, однако очевидно, что это не всегда можно достичь, поскольку территориальное деление носителей этого 
языка может приобретать слишком сложные формы и определение территориальных единиц на основе языкового принципа, вполне закономерно, не может быть совершенным. Поэтому в Хартии региональных языков и языков меньшинств не содержатся требования о том, чтобы территория распространения регионального языка или языка меньшинства обязательно соответствовала территориальному делению. С другой стороны, в Хартии региональных языков и языков меньшинств осуждается практика проведения территориальных реформ таким образом, чтобы усложнять использование или сохранения языка или делить языковые сообщества между несколькими территориальными единицами. Если даже территориальную единицу нельзя адаптировать к ареалу регионального языка, территориальное деление должно, по меньшей мере, оставаться нейтральными и не оказывать негативного влияния на такой язык.

На наш взгляд, статью 16 Рамочной конвенции и статью 1 Европейской Хартии региональных языков и языков меньшинств необходимо корреспондировать со статьей 5 Европейской Хартии местного самоуправления, согласно которой изменения территориальной основы местного самоуправления не могут осуществляться без предварительного выяснения мнения населения соответствующих территорий, возможно путем проведения референдума, если это разрешается законом. Благодаря указанному, в местах компактного проживания национальных меньшинств в основу выяснения мнения местных громад будет объективно положен этнический принцип.

Непременным условием заключения международных договоров Украины с материнскими странами основных этнических меньшинств Украины является принцип сохранения идентичности соответствующих этнических групп [20]. В частности, в Декларации о принципах сотрудничества между Украиной и Венгерской Республикой по обеспечению прав национальных меньшинств от 31.05.1991 [21] закреплено, что стороны заявляют о своей готовности содействовать созданию такого статуса национальных меньшинств, который обеспечит им право на эффективное участие в государственных делах, включая участие в делах, касающихся защиты и поощрения их самобытности, принятия и выполнения решений, имеющих отношение к регионам их проживания. Стороны не примут административных, экономических или иных мероприятий, направленных на ассимиляцию меньшинств или на умышленную изменение пропорций населения территорий, где проживают национальные меньшинства.

В Договоре об отношениях добрососедства и сотрудничества между Украиной и Румынией [22] также закреплено, что стороны будут воздерживаться от принятия мер, которые изменяют пропорциональный состав населения в местностях, где проживают лица, принадлежащие к национальным меньшинствам, направленные на ограничение прав и свобод этих лиц, вытекающих из международных норм и стандартов.

Выводы. Таким образом, в Украине сложилась достаточно целостная 
концепция реформирования территориального деления, которая находится на этапе внедрения. Необходимость проведения территориальной реформы в Украине обусловлена рядом недостатков современной территориальной организации пространственного, управленческого, экономического, социального и т.п. характера. Территориальные трансформации в полиэтнических регионах Украины должны иметь свою специфику н что ориентируют международные стандарты в данной сфере.

\section{Лumepamypa:}

1. The functioning of democratic institutions in Ukraine. Resolution PA CoE 2145(2017).URL:https://assembly.coe.int/nw/xml/XRef/XrefXML2HTMLen.asp?fileid=23453 \&lang=en (дата звернення 27.11.2020).

2. Fourth Report submitted by Ukraine pursuant to Article 25, paragraph 2 of the Framework Convention for the Protection of National Minorities. Resolution ACFC/SR/IV(2016)003. URL : https://rm.coe.int/1680657b74 (дата звернення 27.11.2020).

3. Міжнародний пакт про громадянські і політичні права: Ратифікований Указом Президії Верховної Ради Української РСР від 19.10.73 №2148-VIII. URL : https://zakon.rada.gov.ua/laws/show/995_043 (дата звернення 27.11.2020).

4. Декларація про права осіб, що належать до національних або етнічних, релігійних та мовних меншин : Резолюція Генеральної Асамблеї ООН від 18.12.1992 47/135. URL : https://zakon.rada.gov.ua/laws/show/995_318 (дата звернення 27.11.2020).

5. Товт М.М. Міжнародно-правовий захист національних меншин (тенденції сучасного розвитку): дис... канд. юрид. наук; НАН України, Інститут держави і права ім. В.М.Корецького. К., 2002. 196 арк.

6. Мицик В. В. Права національних меншин у міжнародному праві [Текст] : [монографія] / В. В. Мицик ; Київ. нац. ун-т ім. Т. Шевченка. - К. : Київ. ун-т, 2004. - 287 с.

7. Міжнародна конвенція про ліквідацію всіх форм расової дискримінації : Ратифікована Указом Президії Верховної Ради Української PCP від 21.01.1969. URL. : https://zakon.rada.gov.ua/laws/show/995_105 (дата звернення 27.11.2020).

8. Киценко Д.М. Міжнародно-правовий статус корінних народів: дис... канд. юрид. наук:; Національний ун-т внутрішніх справ. Х., 2003. 238 арк.

9. Декларація про права корінних народів : Резолюція Генеральної Асамблеї ООН від 13.-9.2007 №61/295. URL. : https://zakon.rada.gov.ua/laws/show/995_156 (дата звернення 28.08.2019).

10. Заключний акт Наради з безпеки та співробітницву у Європі. URL : https://zakon.rada.gov.ua/laws/show/994_055?find=1\&text=\%EC\%E5\%ED\%FC\%F8\%E8\%ED (дата звернення 27.11.2020).

11. Гаагські рекомендації про права національних меншин в сфері освіти. URL : https://www.osce.org/uk/hcnm/32194?download=true (дата звернення 27.11.2020).

12. Ословські рекомендації про мовні права національних меншин. URL : https://www.osce.org/uk/hcnm/67545?download=true (дата звернення 27.11.2020).

13. Лундські рекомендації про ефективну участь національних меншин у суспільнополітичному житті. URL : https://www.osce.org/uk/hcnm/32255 (дата звернення 28.08.2019).

14. Равлик I.О., Гев’юк У.Ю. Участь національних меншин у суспільно-політичному житті: Лундські рекомендації та українська практика. Молодий вчений. 2014. № 6(2). С. 180-184.

15. Рамкова конвенція про захист національних меншин : Ратифікована Законом України від 09.12.97 703/97-BP. URL: https://zakon.rada.gov.ua/laws/show/995_055 (дата звернення 27.11.2020).

16. Свропейська Хартія регіональних мов та мов меншин : Ратифікована Законом 
України від 24.12.1999 № 1350-XIV. URL: https://zakon.rada.gov.ua/laws/show/994_014 (дата звернення 27.11.2020).

17. Європейська Хартія місцевого самоврядування : Ратифікована Законом України від 15.07.1997 № 452/97-BP. URL: https://zakon.rada.gov.ua/laws/show/994_036 (дата звернення 27.11.2020).

18. Саган О.Н., Пилипенко Т.І. Свропейські пріоритети державної етнонаціональної політики України: Рамкова конвенція про захист прав національних меншин. К., 2008. 488 с.

19. Невара Л.М. Захист мовних прав у Свропейській хартії регіональних мов або мов меншин: дис. ... канд. юрид. наук; Київ. нац. ун-т ім. Тараса Шевченка. Київ, 2014. - 222 арк.

20. Малюська А.Л. Проблеми співробітництва України з прикордонними державами в контексті забезпечення прав національних меншин (1991 - 2010 рр.) : дис. ... канд. іст. наук; Дип. акад. України. К., 2011. 210 арк.

21. Декларації про принципи співробітництва між Україною та Угорською Республікою по забезпеченню прав національних меншостей від 31.05.1991. URL : https://zakon.rada.gov.ua/laws/show/348_322 (дата звернення 27.11.2020).

22. Договір про відносини добросусідства і співробітництва між Україною та Румунією : Договір ратифіковано Законом України від 17.07.97 №474/97-BP. URL : https://zakon.rada.gov.ua/laws/show/642_003 (дата звернення 27.11.2020).

\section{References:}

1. The functioning of democratic institutions in Ukraine. Resolution PA CoE 2145 (2017). assembly.coe.int. Retrieved from https://assembly.coe.int/nw/xml/XRef/XrefXML2HTMLen. asp? fileid=23453\&lang=en [in English].

2. Fourth Report submitted by Ukraine pursuant to Article 25, paragraph 2 of the Framework Convention for the Protection of National Minorities. Resolution ACFC/SR/IV(2016)003. (2016). rm.coe.int. Retrieved from https://rm.coe.int/1680657b74 [in English].

3. Ukaz Prezydii Verkhovnoi Rady Ukrainskoi RSR "Mizhnarodnyi pakt pro hromadianski i politychni prava" : vid 19.10.73, № 2148-VIII [Decree of the Presidium of the Verkhovna Rada of the Ukrainian SSR "International Covenant on Civil and Political Rights" from 19.10.73, № 2148-VIII]. zakon.rada.gov.ua. Retrieved from https://zakon.rada.gov.ua/laws/show/995_043 [in Ukrainian].

4. Rezoliutsiia Heneralnoi Asamblei OON "Deklaratsiia pro prava osib, shcho nalezhat do natsionalnykh abo etnichnykh, relihiinykh ta movnykh menshyn" : vid 18.12.1992, 47/135 [UN General Assembly Resolution "Declaration on the Rights of Persons Belonging to National or Ethnic, Religious and Linguistic Minorities" from 18.12.1992, 47/135]. Retrieved from https://zakon.rada.gov.ua/laws/show/995_318 [in Ukrainian].

5. Tovt, M.M. (2002). Mizhnarodno-pravovyi zakhyst natsionalnykh menshyn (tendentsii suchasnoho rozvytku) [International legal protection of national minorities (trends of modern development)]. Candidate's thesis. Kyiv: NAN Ukrainy, Instytut derzhavy i prava im. V.M.Koretskoho [in Ukrainian].

6. Mytsyk, V.V. (2004). Prava natsionalnykh menshyn u mizhnarodnomu pravi [Rights of national minorities in international law]. Kyiv: Kyiv. un-t [in Ukrainian].

7. Ukaz Prezydii Verkhovnoi Rady Ukrainskoi RSR "Mizhnarodna konventsiia pro likvidatsiiu vsikh form rasovoi dyskryminatsii" : vid 21.01.1969 [Decree of the Presidium of the Verkhovna Rada of the Ukrainian SSR "International Convention on the Elimination of All Forms of Racial Discrimination" from January 21, 1969]. zakon.rada.gov.ua. Retrieved from https://zakon.rada.gov.ua/laws/show/995_105 [in Ukrainian].

8. Kytsenko, D.M. (2003). Mizhnarodno-pravovyi status korinnykh narodiv [International legal status of indigenous peoples]. Candidate's thesis. Kharkiv: Natsionalnyi un-t vnutrishnikh sprav [in Ukrainian]. 
9. Rezoliutsiia Heneralnoi Asamblei OON "Deklaratsiia pro prava korinnykh narodiv : vid 13.09.2007, № 61/295 [UN General Assembly Resolution "Declaration on the Rights of Indigenous Peoples” from 13.09.2007, №61/295]. zakon.rada.gov.ua. Retrieved from https://zakon.rada.gov.ua/laws/show/995_156 [in Ukrainian].

10. Zakliuchnyi akt Narady z bezpeky ta spivrobitnytsvu u Yevropi [Final Act of the Conference on Security and Cooperation in Europe]. zakon.rada.gov.ua. Retrieved from https://zakon.rada.gov.ua/laws/show/994_055?find=1\&text=\%EC\%E5\%ED\%FC\%F8\%E8\%ED [in Ukrainian].

11. Haahski rekomendatsii pro prava natsionalnykh menshyn v sferi osvity [The Hague Recommendations on the Rights of National Minorities in Education]. (1996). www.osce.org. Retrieved from https://www.osce.org/uk/hcnm/32194?download=true [in Ukrainian].

12. Oslovski rekomendatsii pro movni prava natsionalnykh menshyn [Oslo recommendations on language rights of national minorities]. (1998). www.osce.org. Retrieved from https://www.osce.org/uk/hcnm/67545?download=true [in Ukrainian].

13. Lundski rekomendatsii pro efektyvnu uchast natsionalnykh menshyn u suspilnopolitychnomu zhytti [Lund recommendations on the effective participation of national minorities in socio-political life]. (1999). Retrieved from https://www.osce.org/uk/hcnm/32255 [in Ukrainian].

14. Ravlyk, I.O., Heviuk, U.Yu. (2014). Uchast natsionalnykh menshyn u suspilnopolitychnomu zhytti: Lundski rekomendatsii ta ukrainska praktyka [Participation of national minorities in socio-political life: Lund recommendations and Ukrainian practice]. Molodyi vchenyi - Young scientist, 6(2), 180-184 [in Ukrainian].

15. Zakon Ukrainy "Ramkova konventsiia pro zakhyst natsionalnykh menshyn" : vid 09.12.97, 703/97-VR [Law of Ukraine "Framework Convention for the Protection of National Minorities" from 09.12.97, 703/97-VR]. zakon.rada.gov.ua. Retrieved from https://zakon.rada.gov.ua/laws/show/995_055 [in Ukrainian].

16. Zakon Ukrainy "Yevropeiska Khartiia rehionalnykh mov ta mov menshyn : vid 24.12.1999, № 1350-XIV [Law of Ukraine "European Charter for Regional or Minority Languages" from 24.12.1999, № 1350-XIV]. zakon.rada.gov.ua. Retrieved from https://zakon.rada.gov.ua/laws/show/994_014 [in Ukrainian].

17. Zakon Ukrainy "Yevropeiska Khartiia mistsevoho samovriaduvannia : vid 15.07.1997, № 452/97-VR [Law of Ukraine "European Charter of Local Self-Government” from 15.07.1997, № 452/97-VR]. zakon.rada.gov.ua. $\quad$ Retrieved from https://zakon.rada.gov.ua/laws/show/994_036 [in Ukrainian].

18. Sahan, O.N., Pylypenko, T.I. (2008). Yevropeiski priorytety derzhavnoi etnonatsionalnoi polityky Ukrainy: Ramkova konventsiia pro zakhyst prav natsionalnykh menshyn [European priorities of the state ethno-national policy of Ukraine: Framework Convention for the Protection of National Minorities]. Kyiv [in Ukrainian].

19. Nevara, L.M. (2014). Zakhyst movnykh prav u Yevropeiskii khartii rehionalnykh mov abo mov menshyn [Protection of language rights in the European Charter for Regional or Minority Languages]. Candidate's thesis. Kyiv: Kyiv. nats. un-t im. Tarasa Shevchenka [in Ukrainian].

20. Maliuska, A.L. (2011). Problemy spivrobitnytstva Ukrainy z prykordonnymy derzhavamy v konteksti zabezpechennia prav natsionalnykh menshyn (1991-2010 rr.) [Problems of cooperation of Ukraine with border states in the context of ensuring the rights of national minorities (1991 - 2010)]. Candidate's thesis. Kyiv: Dyp. akad. Ukrainy [in Ukrainian].

21. Deklaratsii pro pryntsypy spivrobitnytstva mizh Ukrainoiu ta Uhorskoiu Respublikoiu po zabezpechenniu prav natsionalnykh menshostei : vid 31.05.1991 [Declaration on the principles of cooperation between Ukraine and the Republic of Hungary on ensuring the rights of national minorities from 31.05.1991]. zakon.rada.gov.ua. Retrieved from https://zakon.rada.gov.ua/laws/show/348_322 [in Ukrainian]. 
22. Zakon Ukrainy "Dohovir pro vidnosyny dobrosusidstva i spivrobitnytstva mizh Ukrainoiu ta Rumuniieiu" : vid 17.07.97 № 474/97-VR [Law of Ukraine "Agreement on good neighborly relations and cooperation between Ukraine and Romania" from 17.07.97, № 474/97VR]. zakon.rada.gov.ua. Retrieved from https://zakon.rada.gov.ua/laws/show/642_003 [in Ukrainian]. 